\title{
FEATURE Conservation practices to mitigate and adapt to climate change
}

Jorge A. Delgado, Peter M. Groffman, Mark A. Nearing, Tom Goddard, Don Reicosky, Rattan Lal, Newell R. Kitchen, Charles W. Rice, Dan Towery, and Paul Salon

C limate change, in combination with the expanding human population, presents a formidable food security challenge: how will we feed a world population that is expected to grow by an additional 2.4 billion people by 2050 ? Population growth and the dynamics of climate change will also exacerbate other issues, such as desertification, deforestation, erosion, degradation of water quality, and depletion of water resources, further complicating the challenge of food security. These factors, together with the fact that energy prices may increase in the future, which will increase the cost of agricultural inputs, such as fertilizer and fuel, make the future of food security a major concern.

Additionally, it has been reported that climate change can increase potential erosion rates, which can lower agricultural productivity by $10 \%$ to $20 \%$ (or more in extreme cases). Climate change could contribute to higher temperatures and evapotranspiration and lower precipitation across some regions. This will add additional pressure to draw irrigation water from some already overexploited aquifers, where the rate of water recharge is lower than the withdrawal rates. These and other water issues exacerbated by climate change present a serious concern because, on average, irrigated system yields are frequently

Jorge A. Delgado is a soil scientist at the USDA Agricultural Research Service, Fort Collins, Colorado. Peter M. Groffman is a microbial ecologist at the Cary Institute of Ecosystems Studies, Milbrook, New York. Mark A. Nearing is a research agricultural engineer at the USDA Agricultural Research Service, Tuscon, Arizona. Tom Goddard is a senior policy advisor at the Government of Alberta, Canada. Don Reicosky is a former soil scientist at the USDA Agricultural Research Service, Morris, Minnesota. Rattan Lal is a professor in the School of Environment \& Natural Resources at the Ohio State University, Columbus, Ohio. Newell R. Kitchen is a soil scientist at the USDA Agricultural Research Service, Columbia, Missouri. Charles W. Rice is a professor of soil microbiology at Kansas State University, Manhattan, Kansas. Dan Towery is the owner of $\mathrm{Ag}$ Conservation Solutions, Lafayette, Indiana. Paul Salon is a member of the SWCS, New York Chapter. double those of nonirrigated systems. The yields of nonirrigated systems could also potentially be reduced due to these stresses. Since there is a direct relationship between soil and water conservation practices and maintaining and/or increasing productivity, the research suggests that without the application of the best soil and water conservation practices, it will not be possible to maintain the productivity levels that are needed to feed the additional billions of people the world is expected to have by 2050. A sound scientific approach that applies concepts in agronomy, soil science, and conservation will be needed to maintain sustainable and productive agricultural systems for stable food security.

With so many large population centers of millions of people who need a steady supply of food, a supply that comes from agricultural fields, ranches, and other agroecosystems that could significantly be impacted by climate change, it is becoming increasingly accepted that systems around the globe will need to apply basic principles of conservation agriculture to maintain/increase agricultural productivity. Hugh Hammond Bennett, who has been called "the father of soil conservation," once said, "From every conceivable angle-economic, social, cultural, public health, national defense-conservation of natural resources is an objective on which all should agree" (USDA NRCS n.d.) Bennett's contributions were part of a larger effort to develop a scientifically sound conservation system, a system that today could serve as a framework not only for climate change mitigation but also for climate change adaptation.

This document is an overview of the science on conservation practices that could potentially be used to mitigate and adapt to climate change. Following is a list that summarizes some basic principles based on a review of peer-reviewed scientific publications. We recommend that these principles be considered, discussed, and even modified as new findings are brought to light that can be used to improve conservation. Meetings of professional sci- entific societies provide opportunities for scientists, conservation practitioners, consultants, farmers, and the general public to get together to share ideas and could be great forums for discussing the principles summarized in this document.

This review of current science strongly suggests that the future of the planet's food security will depend on how water and soil resources are managed today and in the future. These challenges can be met by maximizing soil and water conservation to develop sustainable systems essential to mitigate climate change and adapt to it.

\section{MAJOR WORLD CHALLENGES RELATED TO SOIL AND WATER CONSERVATION}

From conducting a review of the scientific, peer-reviewed literature, we have identified the following major world challenges related to soil and water conservation:

- Climate change is occurring, and the implementation of sound conservation practices will be key for each country's health, social stability, and security. There are a large number of peerreviewed publications that report on the effects of a changing climate. The potential role of conservation practices in contributing to food security is shown in figure 1, which illustrates the relationship between climate change, soil and water resources, and food security.

- Extreme weather events are creating environmental problems, accelerating the rate of erosion, and threatening agricultural production needed for food security. Increases in erosion rates due to climate change will result in lower productivity. Additionally, Hugh Hammond Bennett suggested that without conservation of natural resources, environmental problems such as accelerated erosion could negatively impact society and threaten national security (USDA NRCS n.d.).

- Population growth and the development of new, stronger economies, such as those of China and India are increasing the demand for world resources. By 
2050, the world population is expected to increase by 2.4 billion people, and as the economies of countries with large populations improve, even more pressure will be put on the world's agricultural systems. This increased demand for resources coupled with climate change could threaten the potential to achieve food security.

- Key world agroecosystems that rely on significant amounts of irrigation water are being threatened because water resources are being depleted, a result of water use exceeding water storage replacement. Since irrigated systems have, on average, double the yields of nonirrigated systems, the depletion and salinization of these key world resources results in additional pressure to increase agricultural productivity.

- Due to anticipated impacts from climate change, deforestation, erosion, depletion of water resources, and other environmental problems, as well as potentially higher fuel prices, which could impact agricultural inputs, food security will increasingly become a concern in the coming decades. This could become an even greater concern if extreme events, such as droughts or floods, or even extreme pest or disease outbreaks (e.g., blight, a potato disease that contributed to the infamous potato famine in Ireland) begin to occur on systems that are already stressed.

\section{SOIL AND WATER CONSERVATION PRINCIPLES APPLIED TO CLIMATE CHANGE MITIGATION AND ADAPTATION}

From conducting a review of the scientific, peer-reviewed literature, we have identified principles for (1) communication of soil and water conservation programs, (2) soil and water conservation practices, and (3) development of new science and technologies. These principles, which can be applied to climate change mitigation and adaptation, are listed below:

Principles for Communication of Soil and Water Conservation Programs

- Develop Communication that Connects Science to Land Managers. Better communication with farmers and farmers' groups is key to increasing

\section{Figure 1}

There is a close relationship between climate change, limited global water and soil resources, population growth, and food security. As climate change impacts the world's soil and water resources, it threatens to negatively impact food production (i.e., decrease food production and/or food production potential). As the climate changes, conservation practices have the potential to help us achieve maximum sustainable levels of food production, which will be essential to efforts to feed the world's growing population. Good policies/practices for air, soil, and water conservation will contribute to positive impacts on air, soil, and water quality; soil productivity; and efforts towards achieving and/or maintaining food security. These good policies/practices will contribute to climate change mitigation and adaptation. Poor policies/practices for air, soil, and water conservation (or a lack of policies/practices) will contribute to negative impacts on air, soil, and water quality; soil productivity; and efforts toward achieving and/or maintaining food security.

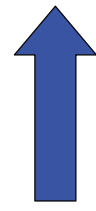

Positive impacts on water quality, soil quality, and air quality

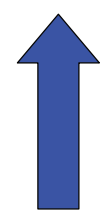

Increases

productivity and potential to achieve food security

Effects of best policies/practices for air, soil, and water conservation that contribute to climate change mitigation and adaptation

Time (Years) and Impacts of Climate Change

Review of the scientific literature shows that the size of the world population is projected to increase with time and that climate change is likely to continue to impact soil and water resources and productivity over time.

Effects of no policies/practices for air, soil, and water conservation and/or poor policies/practices for air, soil, and water conservation that do not contribute to climate change mitigation and adaptation

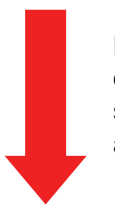

Negative impacts on water quality, soil quality, and air quality

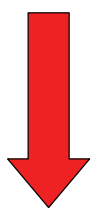

the efficiency of soil and water conservation programs.

- Develop Communication that Connects Science to the Public. Better communication with the general public is essential to increasing awareness of the benefits of soil and water conservation programs.

- Teach the Value of Soil Carbon. Understanding the relationship between carbon (C) sequestration and soil and water quality benefits is key. Conservationists, farmers, policy advisors, K-12, and university students - in short, the general public — should have an understanding of how soil carbon can assist in climate change mitigation and adaptation.

- Embrace Technology. Transfer of new technologies to increase conservation effectiveness will contribute to climate change mitigation and adaption efforts. - Improve Historical Context. Development of long-term data records, programs, and studies are
Decreases

productivity and potential to achieve food security compete to develop the most efficien management practices.

- Enhance Exchange. Forums for exchanging information between farmers, professional societies, scientists, conservation practitioners, and the general public, and to discuss the advantages and disadvantages of recent advances, are needed to continue advancing the field of soil and water conservation and are important for climate change mitigation and adaptation.

Principles for Soil and Water Conservation Practices for Climate Change Mitigation and Adaptation

- Surface Residue Protects. Conservation agriculture increases sustainability. 
- Soil Function Improves with Soil Carbon. Soil C sequestration is beneficial for the environment.

- Cover the Surface. Harvesting of plant residues should be avoided if soil function will be compromised.

- Value Perennial Crops. A large number of peer-reviewed manuscripts report that perennial bioenergy crops (e.g., switchgrass) can contribute to C sequestration and better protect the environment than grain cropping used for energy.

- Embrace Technology. New technologies have the potential to increase conservation effectiveness.

- Off-Field Remediation Practices Are Helpful. Off-the-field conservation practices can contribute to climate change mitigation and adaptation (see examples in table 1 [e.g., riparian forest buffer, wetland]).

- Improve Landscape Diversity with Agroforestry. Agroforestry can contribute to landscape diversity, benefiting the environment.

- Synergism Achieved through Multiple Conservation Practices. Conservation practices often enhance synergism and provide additional benefits by achieving greater efficiency.

- Build on Within-Field Tried and True Practices. There are a series of existing conservation practices, as well as new practices, such as the use of precision/ target conservation, that can contribute to climate change mitigation and adaptation (see examples in table 1).

- Effectiveness Enhanced with Landscape-Targeting Precision Conservation. We need to account for spatial and temporal variability and avoid a one-size-fits-all approach if we are to maximize conservation. The scientific literature has many examples that show that to maximize conservation, managers will need to consider the effects of climate change on yield, productivity, and the environment. These effects are likely to be mixed and to vary greatly by region, by field, within field, and by crop type.

- Promote Energy Efficiency. Green programs can save energy at the farm level (e.g., wind, solar, and biomass programs).

- Value Water More. Water-use efficiency needs to be increased, and water quality needs to be protected.

- Greater Diversity Needed. Diverse cropping systems will be key to mitigating and adapting to climate change. Development of new varieties that can be used for tolerance of drought, temperature stress, and other effects of climate change will be needed.

- Minimize Gas Losses. Practices that can reduce emissions of methane $\left(\mathrm{CH}_{4}\right)$ and other greenhouse gases at the farm level will contribute to sustainability.

- "Tighter" Nutrient Cycles. Practices that can capture nutrients and energy from manure contribute to conservation. Cycling of crop residues, use of cover crops, and increasing fertilizer-use efficiencies are some examples of ways to contribute to tighter nutrient cycles.

Principles for Development of New Science and Technologies

- Research Pays Dividends Long Term. Research programs greatly contribute to soil and water conservation, making them important for climate change mitigation and adaptation.

\section{CLIMATE CHANGE: CHALLENGES AND OPPORTUNITIES}

Greenhouse gases (GHG) emitted into the atmosphere by human activities have increased radiative forcing and have been reported to be contributing to an increase in global mean temperature of approximately $0.74^{\circ} \mathrm{C}\left(1.33^{\circ} \mathrm{F}\right)$ over the past century (IPCC 2007). Estimates of projected temperature increases over the 21 st century range between approximately $1.8^{\circ} \mathrm{C}$ and $4.9^{\circ} \mathrm{C}\left(3.2^{\circ} \mathrm{F}\right.$ and $\left.8.8^{\circ} \mathrm{F}\right)$ (IPCC 2007). Primary anthropogenic GHGs contributing to this increased radiative forcing are carbon dioxide $\left(\mathrm{CO}_{2}\right), \mathrm{CH}_{4}$, and nitrous oxide $\left(\mathrm{N}_{2} \mathrm{O}\right)$. Future projections indicate temperature increases generally consistent with historical trends, with the greatest temperature increases over land and at high northern latitudes and less warming over the southern hemisphere.
Increases in atmospheric and surface temperatures lead directly to increases in evaporation rates of water at the Earth's surface as well as to an increase of about $7 \%$ per degree Celsius in the capacity of the atmosphere to hold moisture (IPCC 2007). These factors lead to a more vigorous hydrologic cycle, influencing precipitation amounts, intensities, frequencies, and extremes. In the United States, measured data show an increase in overall average annual precipitation of $10 \%$ between 1910 and 1996 (Karl and Knight 1998), and other sources report upward historic trends ranging from $6 \%$ to $8 \%$ over the 20th century for the central and eastern United States, northern Europe, and both northern and central Asia (IPCC 2007). However, projections for many areas of the world that are already water stressed, including the southwestern United States and parts of Africa, indicate a drier future. Rainfall intensities have increased in many parts of the world over the last few decades, including in the United States, and future projections are for increases in precipitation intensities across much of the Earth (IPCC 2007).

Reports on the expected consequences of climate change can be found throughout the peer-reviewed literature (USEPA 2010a). Expected impacts range from higher erosion rates due to extreme precipitation events in some areas, while droughts and lower precipitation in other areas may lower biomass productivity and increase the potential for wind erosion (Nearing et al. 2004; Hatfield and Prueger 2004). Additionally, warmer temperatures can also contribute to earlier snow melt, increasing earlier flows and decreasing water availability later on during the growing season. In terms of soil conservation, the expected consequences of future climate change include changes to soil erosion rates and associated water quality problems (IPCC 2007) as well as the need to adjust the conservation planning process to meet continually changing rainfall intensities. With respect to water conservation, the issues (e.g., water balances, evapotranspiration) are extremely diverse and complex. After extensive analyses, the IPCC summarized that the negative 


\section{Table 1}

The majority of this table is adapted from Eagle et al. (2010). Other results from Adler et al. (2007) life cycle analysis of bioenergy systems and from a matrix of conservation practices developed by USDA Natural Resources Conservation Service (NRCS), West Technology Center, were also incorporated, as well as additional comments from the authors of this document. The effect of management practices on soil carbon sequestration (CS), the net flux of nitrous oxide and methane greenhouse gas (GHG) emissions, and on the change in upstream and process emissions (UPE, fuel, fertilizer, etc.) are estimated. All estimated values were expressed as equivalents of carbon dioxide. A positive, high, and very high sequestration potential are represented by,+++ , and +++ , respectively, while net equivalent emissions are represented by -. The net carbon sequestration impact (NCSI) is the sum of CS, GHG and UPE.

\begin{tabular}{|c|c|c|}
\hline Management practice* & CS G & G Additional benefits to the producer and environment \\
\hline \multicolumn{3}{|l|}{ Agroforestry } \\
\hline $\begin{array}{l}\text { Windbreaks for crops } \\
\text { and livestock }\end{array}$ & +++ & $\begin{array}{l}\text { Improves crop and livestock protection and wildlife habitat. Provides alternative income source. } \\
\text { Has potential to contribute to adaptation (e.g., minimize impacts of extreme wind storms). }\end{array}$ \\
\hline $\begin{array}{l}\text { Silvopasture with } \\
\text { rotational grazing }\end{array}$ & +++ & $\begin{array}{l}\text { Provides annual income from grazing; long-term income from wood products. Has potential to contribute } \\
\text { to adaptation (e.g., provide a viable income and serve as a tool against a changing climate). }\end{array}$ \\
\hline Riparian forest buffer & +++ & $\begin{array}{l}\text { Improves water quality and wildlife habitat. Provides alternative income source (specialty crops, } \\
\text { hunting fees). Has potential to contribute to adaptation (e.g., use targeted, } \\
\text { strategically located riparian forests to reduce impacts of extreme events due to higher water flow). }\end{array}$ \\
\hline
\end{tabular}

\section{Livestock}

Organic soil amendments (especially manure)

Rotational grazing

Improve grazing management rangeland

\section{Cropland}

Change from conventional to conservation tillage

Change from conventional to no-till

Improved irrigation

management

Crop diversity crop rotation

Crop conversion to pasture

$+\quad+$ Provides nutrients for crops; improves water quality when nutrient management plans are followed and manure is not over applied. Has potential to contribute to adaptation (e.g., result in higher nutrient cycling capacity and soils with improved soil quality that may be able to adapt better and maintain productivity in a changing climate).

++ Reduces water requirements. Helps withstand drought. Increases long-term grassland productivity. Has potential to contribute to adaptation (e.g., provide economic alternative due to higher-quality forage).

$++\quad$ Potentially increases carbon sequestration on land, depending on previous crop(s) grown. Has potential to contribute to adaptation (e.g., provide economic alternative due to improved grasslands and soils with improved soil quality that may be able to adapt better and maintain productivity in a changing climate).

$+\quad+\quad$ Improves soil, water, and air quality. Reduces soil erosion and fuel use; saves expenses, time, and labor. Has potential to contribute to adaptation (e.g., provide economic alternative due to savings in energy).

+ - Improves soil, water, and air quality. Reduces soil erosion and fuel use; saves expenses, time, and labor. Has potential to contribute to adaptation (e.g., provide economic alternative due to savings in energy).

$+\quad+\quad$ Improves air quality, reduces water quantity usage. Has potential to contribute to adaptation, since saving water (reduced usage) will be crucial in the coming decades to deal with a changing climate in drier regions and to respond to droughts.

$+\quad+$ Reduces erosion and water requirements. Improves soil and water quality, reduces nitrogen and other fossil-fuel-intensive inputs. Has potential to contribute to adaptation (e.g., provide economic alternative that may be able to adapt better and maintain productivity in a changing climate that could bring new pests and diseases due to warmer weather).

$++\quad$ Reduces erosion and increases carbon sequestration. Has potential to contribute to adaptation (e.g., provide economic alternative that may be able to adapt better and maintain economic productivity in a changing climate).

Effective nitrogen management na + Reducing losses of reactive nitrogen can contribute to improved water quality; saves expenses, (use of slow-release fertilizer, nitrification inhibitors, higher use efficiency, lower rates) Cover crops

Crop conversion to natural Improved grazing management Change from annual to perennial crop

Biochar application

Wetland restoration

Change from annual to switchgrass bioenergy system

Change from annual to hybrid poplar bioenergy system time, and labor. Can reduce losses via ammonia volatilization.

$+\quad+\quad$ Reduces erosion and contributes to soil and water quality. In some cases can contribute to increased economic returns from the following crop. Can be used as biocontrol and reduce chemical inputs. Has potential to contribute to adaptation (e.g., provide economic alternative that may be able to improve yields of subsequent crops and help in weed and pest management).

++ Reduces erosion and contributes to soil and water quality.

++ Reduces erosion and increases carbon sequestration.

++ Reduces erosion and contributes to soil and water quality.

$++\quad$ Increases carbon sequestration.

$++\quad$ Wildlife and other ecological benefits derived from easement (water quality, flood retention). Has potential to contribute to adaptation (e.g., use targeted, strategically located riparian forest that can be used to reduce impacts of extreme events due to higher water flow).

$+\quad+\quad$ Can serve as a net sink for carbon sequestration across life cycle analysis. Has potential to contribute to adaptation (e.g., provide economic alternative, with improved soil quality that may be able to adapt better and maintain productivity in a changing climate).

$+\quad+\quad$ Can serve as a net sink for carbon sequestration across a life cycle analysis. Has potential to contribute to adaptation (e.g., potential to provide economic alternative, with improved soil quality that may be able to adapt better and maintain productivity in a changing climate).
UPE NCS

$+\quad+++$

$+\quad+$

$+\quad+++$

(n)

$+\quad++$

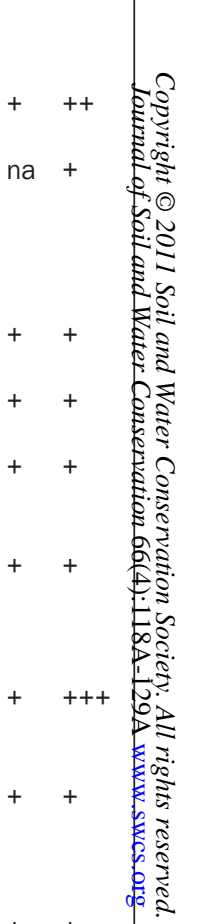

(1)

$+\quad+++$

na ++

$+\quad++$

$+\quad+++$

$+\quad++$

$+$

$+\quad+$

Notes: Symbols,+++ , and +++ indicate that the mean $\mathrm{CO}_{2}$ sequestration is 0 to 2 ; $>2$ to 4 ; and $>4 \mathrm{t} \mathrm{ha}^{-1} \mathrm{y}^{-1}$, respectively. Symbol - indicates that there are net emissions of $\mathrm{CO}_{2}$ at a rate of 0 to $2 \mathrm{tha}^{-1} \mathrm{y}^{-1}$. na indicates that no data was available.

* This table presents and compares select conservation practices. We acknowledge that many other conservation practices exist that are not covered in this table, which was presented to show examples of how conservation practices can contribute to climate change mitigation and adaptation. 
impacts of climate change on freshwater systems will outweigh benefits (IPCC 2007). These and other expected effects from climate change have the potential to contribute to major problems associated with ecosystem services, energy, health and disease, food and fiber production, rises in sea level, and other areas.

\section{THE CARBON AND NITROGEN CYCLES AND AGRICULTURAL INFLUENCES ON GREENHOUSE GASES}

Greenhouse Gases Contributed by Agriculture are an Important Factor in Climate Change. Agriculture plays an important role in the GHG fluxes of $\mathrm{CO}_{2}$, $\mathrm{N}_{2} \mathrm{O}$ and $\mathrm{CH}_{4}$, contributing $6 \%$ of total United States GHG emissions, a total of 427.5 $\mathrm{Tg} \mathrm{CO}_{2}$ equivalents (table 2; figure 2) (USEPA 2010b). The most important agricultural GHG fluxes are $\mathrm{N}_{2} \mathrm{O}$ emissions associated with agricultural soil management (215.5 $\mathrm{Tg} \mathrm{\textrm {CO } _ { 2 }}$ equivalents) and $\mathrm{CH}_{4}$ associated with enteric fermentation (140.8 $\mathrm{Tg} \mathrm{CO}_{2}$ equivalents). Other important agricultural sources are $\mathrm{CH}_{4}$ and $\mathrm{N}_{2} \mathrm{O}$ from manure management and $\mathrm{CO}_{2}$ from fossil fuel combusted during farming activities. These emissions are increasing; between 1990 and 2008, $\mathrm{CH}_{4}$ emissions associated with agriculture increased by $14.4 \%$, while $\mathrm{N}_{2} \mathrm{O}$ emissions have increased by $7.0 \%$ over the same period (table 2; figure 2) (USEPA 2010b).

Carbon Cycle Overview and Where Greenhouse Gases Come From with Respect to Agriculture. Agricultural emissions of $\mathrm{CO}_{2}$ and $\mathrm{CH}_{4}$ are strongly linked

\section{Figure 2}

Influences of agricultural practices on greenhouse gases in the United States (USEPA 2010b).

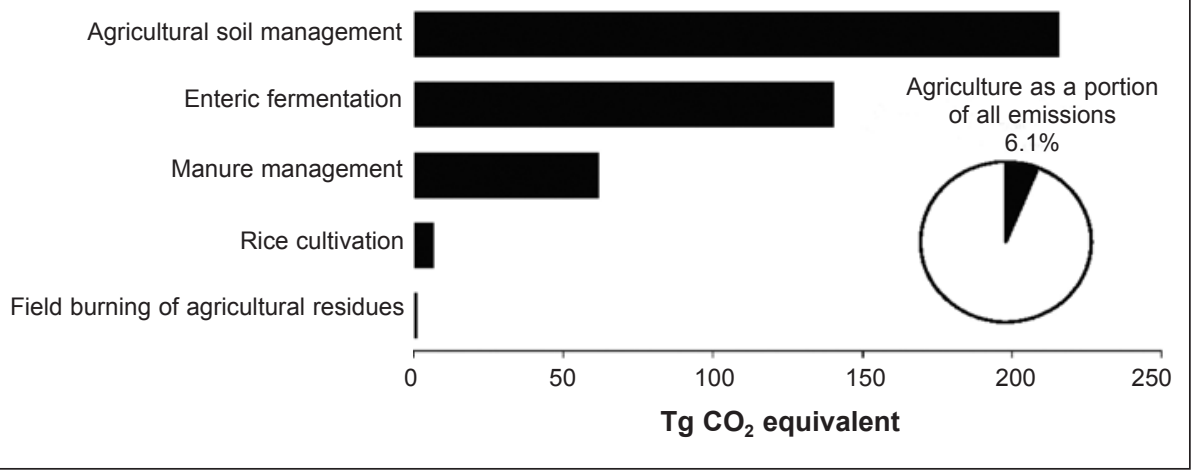

to the $\mathrm{C}$ cycle and to measured impacts on atmospheric $\mathrm{C}$ concentrations. In addition to fossil fuel combustion associated with general farming activities, cultivation and harvest reduce soil organic matter and $\mathrm{C}$ content, resulting in a significant, albeit transient transfer of $\mathrm{C}$ from soil to the atmosphere. Methane is produced under the anaerobic conditions present in the rumen of cattle, and thus enteric fermentation is a major source of GHG emissions. Manure piles also support the anaerobic conditions that support $\mathrm{CH}_{4}$ production.

Nitrogen Cycle Overview and Where Greenhouse Gases Come From with Respect to Agricultural Nitrous Oxide. Nitrogen fertilizer use is the dominant source of $\mathrm{N}_{2} \mathrm{O}$ emissions from agriculture, as this gas is produced as a byproduct of numerous nitrogen $(\mathrm{N})$ cycle transformations in soil, especially nitrification and denitrification. In addition to "direct" emissions from fertilized fields, there is a need to account for "indirect" emissions that occur as $\mathrm{N}$ leaves agricultural fields via leaching and/or is lost as runoff and through ammonia-N/ $\mathrm{NO}_{\mathrm{x}}-\mathrm{N}$ volatilization and is processed (with associated $\mathrm{N}_{2} \mathrm{O}$ release) as it travels through groundwater, streams, and estuaries.

\section{CONSERVATION PRACTICES TO MITIGATE GREENHOUSE GASES EMISSIONS AND ADAPT TO CLIMATE CHANGE}

Despite the great achievements in food production that occurred during the Green Revolution, the potential effects of climate change have raised concerns about the future of food security (Verdin et al. 2005; Montgomery 2007; Bryan et al. 2009). These concerns are not new; a few centuries ago Reverend Thomas Malthus proposed that agricultural production would not keep up with population growth, resulting in hunger and famine.

Table 2

Emissions from agriculture in the United States ( $\mathrm{Tg} \mathrm{CO}_{2}$ equivalent) (USEPA 2010b).

\begin{tabular}{|c|c|c|c|c|c|c|c|}
\hline Gas/Source & 1990 & 1995 & 2000 & 2005 & 2006 & 2007 & 2008 \\
\hline Enteric fermentation & 132.4 & 143.7 & 136.8 & 136.7 & 139.0 & 141.2 & 140.8 \\
\hline Rice cultivation & 7.1 & 7.6 & 7.5 & 6.8 & 5.9 & 6.2 & 7.2 \\
\hline Field burning of agricultural residues & 0.8 & 0.7 & 0.9 & 0.9 & 0.9 & 1.0 & 1.0 \\
\hline $\mathrm{N}_{2} \mathrm{O}$ & 218.3 & 221.8 & 227.2 & 233.0 & 229.1 & 228.8 & 233.5 \\
\hline Manure management & 14.4 & 15.5 & 16.7 & 16.6 & 17.3 & 17.3 & 17.1 \\
\hline Field burning of agricultutal residues & 0.4 & 0.4 & 0.5 & 0.5 & 0.5 & 0.5 & 0.5 \\
\hline Total & 387.8 & 407.7 & 410.9 & 419.7 & 417.2 & 423.0 & 427.5 \\
\hline
\end{tabular}


The 20th century's Green Revolution showed that science-based solutions could provide answers to global challenges to the benefit of societies. Despite the success of the Green Revolution, today there are new concerns, and the threat of climate change is among the most severe threats that face our planet in the 21st century (USDA NRCS 2010). Additionally, climate change, and the potential occurrence of extreme weather events could affect yields across large, productive regions of the United States and the world, and together with other concerns, could impact food security and resource availability. It is, therefore, essential that we act immediately to help counter these impending global issues, through mitigation and adaptation (figure 1).

Some of these concerns that can interact with climate change and extreme weather events are desertification, deforestation, depletion of groundwater resources, plant diseases, and population growth and higher demand for food production. Another concern that could affect the maximization of yields is energy costs, which are expected to rise in the future and which may reduce key fertilizer and agrochemicals inputs at a farm level (UNEP GRID-Arendal 2009). There is no doubt that as we look ahead to the next four decades, there will be a great need to maximize production due to the growing food demand that comes with population growth. It is clear that the interaction of all these emerging problems has the potential to create a food security problem that threatens global security.

Climate change could add additional pressure to productive, irrigated regions around the world that are already overexploited, contributing to the depletion of some groundwater resources. Additionally, there are reports that for some regions, the melting of glaciers may affect the availability of water that is used for cities and/or irrigated lands. This presents a serious concern because, on average, irrigated systems have yields that are twice those of nonirrigated systems (Rangely 1987; Bucks et al. 1990; Tribe 1994). Nonirrigated systems could also see their yields potentially reduced due to these stresses since it has been reported that for every increase in temperature of $1^{\circ} \mathrm{C}\left(1.8^{\circ} \mathrm{F}\right)$, there is a potential reduction in yield, not only from heat stress, but also from the interaction of heat stress and drought stress that may be put on crops (Peng et al.2004; Auffhammer 2011; Lobell et al. 2011). For example, across Africa, an increase in temperature of $1^{\circ} \mathrm{C}$ under drought conditions could affect $100 \%$ of the maize area, potentially reducing yields by at least 20\% (Auffhammer 2011; Lobell et al. 2011). Additionally, climate change can increase the potential for higher erosion rates, which is also of concern because erosion has been reported to lower agricultural productivity by $10 \%$ to 20\% (Quine and Zhang 2002; Cruse and Herndel 2009).

In other words, faced with the need to increase yields over the next few decades to feed the growing human population, it is essential to act immediately to implement soil and water conservation practices to mitigate climate change and adapt to its effects to help ensure food security (figure 1). Hugh Hammond Bennett was a leader in conservation who led an effort to minimize erosion events, such as the Dust Bowl, and who contributed to the implementation of a scientifically sound conservation system in the United States, a system that can be used today as a framework for climate change mitigation and adaptation.

The literature is full of examples where conservation practices can be used to mitigate and adapt to climate change (Lal 2002; Eagle et al. 2010; Johnson et al. 2010). Conservation agriculture can be used across different world agroecosystems, ranging from highly intensive agriculture to small-farm and/or sustainable agriculture, to help us mitigate and adapt to climate change (FAO 2009; Thiombiano and Meshack 2009; Eagle et al. 2010; Johnson et al. 2010; Silici 2010). In intensive agriculture, cover crops with limited irrigation can contribute to increased yields of the subsequent crop (e.g., potatoes) and increased water and $\mathrm{N}$ use efficiencies in the system, while reducing potential erosion and $\mathrm{N}$ losses to the environment (Delgado et al. 2007).

Atmospheric $\mathrm{C}$ can be fixed by crops via the photosynthesis process, releasing oxygen. This fixed atmospheric C is returned to soils when crop residue is incorporated and/or returned to the soil surface. Additionally, the fixed atmospheric $\mathrm{C}$ is also translocated belowground to root systems. Practices that increase the return of crop residue to the soil, especially when using crops that produce large amounts of residue and have deep-rooted systems (e.g., corn, wheat, barley) or forages that also have deeply rooted systems and produce a large amount of aboveground biomass, can accelerate atmospheric C sequestration in soils. Conservation practices with respect to crops, livestock, agroforestry, and forestry can contribute to sequestration of atmospheric $\mathrm{C}$ in agricultural soils, reduction of GHG, and reduction of fossil fuel consumption (table 1).

Eagle et al. (2010) reported that switching from conventional tillage to either no-till or to conservation agriculture would increase the net $\mathrm{C}$ sequestration potential for agricultural lands in the United States. Even when changes in processes and upstream emissions were considered, no-till and conservation agriculture sequestered more $\mathrm{C}$ than conventional tillage practices. Eagle et al. (2010) reported that other conservation practices that showed similar increases in direct and indirect $C$ sequestration potential were (1) using cover crops, (2) diversifying annual cropping systems, (3) including perennial crops in rotations, (4) changing from annual to perennial crops, (5) using organic soil amendments (especially manure), (6) reducing fertilizer-N use, (7) changing the type of fertilizer used (e.g., a change to controlled-release fertilizers), (8) using nitrification inhibitors, (9) improving grazing management, (10) changing cropland to pasture, (11) converting cropland to natural areas, and (12) restoring wetlands.

Carbon sequestration is important in climate change adaptation efforts since it contributes to so many soil functions and properties that are related to productivity. For example, C sequestration helps improve soil properties, such as soil structure and aggregate formation, which contribute to increases in available water holding capacity. It also increases porosity, improving drainage, permeability, and much-needed aeration for adequate root 
functioning. From a soil fertility standpoint, $\mathrm{C}$ sequestration increases the cation exchange capacity (CEC) of soils and is a key for storage of essential crop nutrients such as N, phosphorous, sulfur, and other macro and micronutrients. This storage could accumulate (sequester) essential crop macro and micronutrients for future needs and would be a good adaptation practice against climate change, especially if energy prices rise in the future, since storage would help contribute to the maintenance of yields and economic returns for farmers.

Eagle et al. (2010) reported that practices that help increase $\mathrm{N}$-use efficiency (e.g., lower $\mathrm{N}$ application rates, controlled-release fertilizers, and nitrification inhibitors) will be good mitigation practices since they reduce $\mathrm{N}_{2} \mathrm{O}$ emissions, contributing to net $\mathrm{C}$ sequestration equivalents. The use of new technologies to implement precise nutrient management can be described as practices that apply the right input in the right amount to the right place at the right time in the right manner (i.e., the $4 \mathrm{Rs}$ ) (Roberts 2007). Precision farming can help farmers improve $\mathrm{N}$ fertilizer applications, minimizing $\mathrm{N}$ inputs and $\mathrm{N}$ losses to the environment. Additionally, precision conservation (or target conservation) practices can help maximize the effectiveness of conservation practices by reducing erosion and increasing $\mathrm{C}$ sequestration while considering spatial and temporal variability (Berry et al. 2003; Pennock 2005; Walter et al. 2007).

Agroforestry (e.g., alley cropping, silvopasture, riparian buffers, tree-grass buffer, and windbreaks) can potentially be used to sequester C. Agroforestry is an excellent climate change mitigation tool since it can sequester significant amounts of $\mathrm{C}$ from the atmosphere (Mutuo et al. 2005). Well-managed agroforestry could also be integrated with bioenergy production and could reduce GHG emissions due to its low use of fertilizer inputs and energy (Eagle et al. 2010).

Johnson et al. (2007) conducted an indepth review on biomass/bioenergy crops, such as grain ethanol, biodiesel, and cellulosic biomass in the United States, and analyzed some of the production and environmental issues related to these fuel systems. Their conclusion was that biomass from crop residue (straw, stover) should not be harvested for bioenergy unless soil protection needs have been achieved in the system, in order to avoid negative impacts to the sustainability of the cropping system. Johnson et al. (2007) concluded that harvesting biomass from perennial biomass/bioenergy cover crops provides several advantages. One advantage is that these perennial biomass/bioenergy systems need smaller inputs of $\mathrm{N}$, pesticides, and herbicides, minimizing off-site environmental impacts. Additionally, their higher aboveground litter production, in conjunction with larger-rooting systems, contributes to increased $\mathrm{C}$ sequestration. A third advantage is that these perennial biomass/bioenergy systems typically will require zero to minimum tillage, contributing to greater $\mathrm{C}$ sequestration potential, lower soil erosion, and better soil quality. Finally, these perennial biomass/bioenergy systems will even serve as habitats for wildlife, expanding game and the ecosystem services that they provide.

In an analysis of biomass-bioenergy systems in the United States conducted by Johnson et al. (2007), it was concluded that a viable biofuel system should (1) be economical on large scales, (2) not deplete food supplies, (3) provide more energy than what it uses, and (4) provide environmental benefits (e.g., reductions of GHG). The life cycle analysis by Adler et al. (2007) and the analysis of biomass/bioenergy crops in the United States by Johnson et al. (2007) show that the most beneficial systems for maximizing $\mathrm{C}$ sequestration and environmental conservation and for minimizing potential competing demands for the crop as a fuel or food source are the switchgrass and hybrid poplar bioenergy systems.

New research is reporting that algae farms can potentially be a source of bioenergy (Schenk et al. 2008; Batan et al. 2010). Some new research has suggested there is potential to recycle saline water from horticultural and floral greenhouse operations to grow algae to produce biomass/fuel (e.g., diesel). We need additional research on how to develop a viable algae biofuel industry that conserves soil and water while reducing GHGs and sequestering C.

Crop rotations are a key conservation practice in the mitigation of climate change (Eagle et al. 2010). Using cover crops and/ or adding a leguminous crop into the rotation can also increase the potential for $\mathrm{N}$ cycling and for higher $\mathrm{N}$-use efficiencies, reducing the need for fertilizer inputs and potentially contributing to lower $\mathrm{N}_{2} \mathrm{O}$ emissions. Modeling simulations and ${ }^{15} \mathrm{~N}$ analysis have suggested that using cover crops and/or cycling crop residue with high $\mathrm{C}: \mathrm{N}$ ratios could potentially contribute to reduced $\mathrm{N}_{2} \mathrm{O}$ emissions and nitrate-leaching potential, since the $\mathrm{N}$ losses to the environment were significantly lower from crop residue with high $\mathrm{C}: \mathrm{N}$ ratios and/or cover crops residue than losses from readily available fertilizer (Delgado 2010; Delgado et al. 2010). Cropping systems can be used as tools to increase nitrogen use efficiency, improve soil and water quality, and contribute to the sequestration of atmospheric C.

Management practices that also consider the hydrological cycle have the potential to maximize productivity while reducing losses of reactive $\mathrm{N}$ to the environment. More efficient irrigation systems (e.g., drip irrigation, center pivot irrigation, surge irrigation, scheduling irrigation) can contribute to reduced leaching losses. These irrigation systems/management practices that can increase water use efficiencies will be important for climate change adaptation in the southwestern United States, especially since projections of future climate change scenarios for this region suggest higher temperatures and drier weather in the future. Additionally, development of new, more drought-resistant crop varieties will be important for climate change adaptation. Research on how to maximize yields under limited irrigation will also be important for responding to the projected drier future scenarios for the southwestern United States.

Models are tools that can help us assess what benefits, such as increasing $\mathrm{C}$ sequestration and reducing $\mathrm{GHG}$ emissions, may be gained from the conservation practice(s) under assessment. Additionally, long-term monitoring programs, such as the Long Term Ecological 
Research (LTER) Network (http://www. lternet.edu/), GHG Reduction through Agricultural Carbon Enhancement network) (GRACEnet) (Jawson et al. 2005), and Conservation Effects Assessment Project (CEAP) (Mausbach and Dedrick 2004), can contribute to assessments of conservation practices and their effectiveness in mitigating and adapting to climate change.

Conservation practices will provide farmers with alternative management strategies that can help them deal with a changing climate (e.g., droughts or other extreme weather events). Some of these conservation practices will also contribute to increased economic returns for the farmers. Additionally, there is potential to have strong, viable bioenergy production that could help conserve soil systems to protect soil and water quality, making these soil systems available for future generations if an increase in population will require the transfer of these resources to crop production. There is also a need to help transfer future advances in conservation practices and/or new tools and technologies (e.g., precision farming/precision conservation tools) to farmers, so communication with farmers, farmer groups, consultants, Certified Crop Advisors, and the general public is essential.

NO-TILL AND CARBON SEQUESTRATION

There is compelling evidence that intensive/inversion tillage of our agricultural ecosystems can contribute to environmental degradation. This environmental degradation, along with the expanding human population, is putting tremendous pressure on Earth's resources and requires that we change our agricultural practices to ensure food security. These changes must align with principles of conservation agriculture: (1) minimum soil tillage disturbance, (2) diverse crop rotations and/ or cover crops, and (3) continuous plant residue cover, loosely described as no-till/ direct seeding systems. Although conservation agriculture (no-till and direct seeding) can be highly effective conservation, no-till is not a silver bullet that will solve all the environmental problems in all site-specific situations. No-till is part of a larger, evolving vision of sustainable agriculture in which a diversity of farming methods is considered healthy, and wherever it is economically viable to do so, farmers should integrate all aspects of conservation agriculture as part of agriculture's transition to sustainability.

The foundation underlying the three main principles of conservation agriculture is how management factors interact with and contribute to soil $\mathrm{C}$, the primary determinant of soil quality. Minimum soil disturbance requires less fossil fuel energy use and less direct $\mathrm{C}$ emissions from the soil. Because most agricultural crop residues are $40 \%$ to $50 \% \mathrm{C}$ on a dry weight basis, their presence and management on the soil surface become extremely important in minimizing soil loss from water, wind, and tillage erosion, and for maintaining and/or increasing soil quality, soil organic C, and soil fauna activity. While there are still scientific debates about the relative amount of $\mathrm{C}$ sequestered using no-till/direct seeding techniques, the other ecosystem services provided by low soil disturbance far outweigh the amount of $\mathrm{C}$ sequestered in the landscape.

Site-specific properties are also critically important. Understanding the relationship between $\mathrm{C}$ and $\mathrm{N}$ through the $\mathrm{C}: \mathrm{N}$ ratio in the soil and crop residue becomes more important when integrated with nutrient management. Other crop residue properties besides $\mathrm{C}: \mathrm{N}$ ratios, such as lignin and polyphenolics, can determine short-term residue $\mathrm{N}$ mineralization. Other sitespecific factors, such as soil texture, the hydrologic cycle, temperature, and other physical, chemical, and biological properties, can affect the $\mathrm{C}$ and $\mathrm{N}$ dynamics and should be considered in nutrient management. A clearer understanding of the integration of factors that affect GHG emissions can potentially be a major contributor to climate change mitigation, suggesting a need for further research in this area. Site-specific precision conservation practices can be used to increase conservation effectiveness, increase $\mathrm{N}$-use efficiency, protect water quality, manage crop residue, and mitigate and adapt to climate change.

There is a need for more research on how food production can be enhanced while minimizing human impacts to environmental quality. Additionally, the expanding global population necessitates further research on developing sustainable food production systems on the very limited and fragile soil systems that support civilization. Finally, more conservation practices with an emphasis on minimum soil disturbance and maximum $\mathrm{C}$ management will be required for the sustainable production so important to future generations.

\section{CURRENT MITIGATION AND ADAPTATION EFFORTS AND FINDINGS FROM RESEARCH}

Global industry and government leaders gather for an annual Economic Summit in Davos, Switzerland, to discuss major global issues and trends. In their 2011 Global Risks report, they determined that climate change is a risk most likely to occur and that will result in the largest impact (in economic terms) of any of the risks studied (WEF 2011). The report also highlights three key nexus of interrelated risks to alert the world to. One is the "food-water-energy" security nexus. Due to population and industrial growth, the report forecasts an increase in food demand of $50 \%$, water demand of $40 \%$, and energy demand of $40 \%$ over the next two decades. Climate change will be further stimulated by a surge in energy demand. Water will be used for urban purposes, and some will be used to produce bioenergy crops, leaving food crops to compete for increasingly limited access. Natural resources around the world will be under pressure (Lemmen and Warren 2004; Iglesias et al. 2007; IPCC 2007; UNFCC 2007; CCSP 2008; Gleick et al. 2010; Ramanathan and Xu 2010; USDA NRCS 2010).

The Stern report (Stern 2006) from the United Kingdom suggested that countries should dedicate $1 \%$ of their gross domestic product to curbing climate change. A recent Organization for Economic Cooperation and Development modeling paper determined that in developing countries, this number would be higher than in developed economies. Thus, a greater burden is in the future for developing countries, many of which have forecasts for drier climates and extreme weather. The climate change overlay on 
developing economies will not only put natural resources at greater risks but will challenge sectoral development and aggravate poverty (IPCC 2007; UNFCC 2007; Gleick et al. 2010; Lybbert and Sumner 2010; Ramanathan and Xu 2010; USDA NRCS 2010).

Most developed countries have completed some assessment of climate change impacts and adaptation. Significant efforts have been put towards prediction of future climate. Agreement amongst various models often points towards warmer, drier weather with longer frost-free periods in northern latitudes and greater occurrence of drought in southern latitudes. Of course, on a planet as large as Earth, a broad range of effects might be expected. For the United States, the eastern and southern regions may see increases in precipitation and hurricane intensities that could increase the risks of flooding and crop damage (Madsen and Figdor 2007), while the western United States could experience severe droughts (Cayan et al. 2010). Extreme weather events are predicted to increase, although quantification estimates are still elusive. Research is also needed in improving models for predicting weather and assessing potential impacts to agriculture.

Adaptation efforts have been elementary to date. Energy efficiency programs have encouraged green energy and consumer awareness. It is important to stay cognizant of the diverse timelines of different sectors. Agriculture may be the most resilient or adaptable sector to climate change as crops, livestock, and fish have relatively short life spans, which allow farmers to try new types, genetics, or management practices of crops to suite changing conditions.

Some work has already been done towards developing drought-tolerant crops and increasing water-use efficiency and nutrient cycle efficiency. Research that monitors both climate and natural resource trends in the long term as well as research in adaptive and mitigating conservation practices are needed. A recent global response with nearly 30 countries agreeing to cooperate formed the Global Research Alliance on Agricultural Greenhouse Gases (http://www.glob- alresearchalliance.org/) and underscores that realization.

Examples of Mitigation Strategies for Agricultural Production

1. Increasing soil C sequestration to improve soil functions.

2. Reducing $\mathrm{CH}_{4}$ emissions from ruminants with feeding management, use of edible oils, and possible vaccinations.

3. Using slow-release $N$ fertilizers with proper timing, placement, and rates to minimize $\mathrm{N}_{2} \mathrm{O}$ emissions.

4. Increasing $\mathrm{N}$-use efficiencies for cropping systems.

5. Capturing nutrients and energy from manure, crop residue, and cover crop management (close the nutrient cycles).

6. Using more efficient power sources and renewable energy (more efficient tractors, green power).

Examples of Soil and Water Adaptation Needs for Climate Change

1. Erosion prevention and protection from extreme weather events, which may be more damaging in the future.

2. Irrigation infrastructure to reduce water losses and increase irrigation efficiencies and irrigation practices that contribute to conservation of water quality.

3. More diverse cropping systems to adapt to variable climates and new pest and disease pressures.

4. Developing crop varieties that are drought-tolerant and more resistant to heat stress, with higher $\mathrm{N}$-use efficiencies, and/or if needed, with a lower $\mathrm{N}$ sink (lower $\mathrm{N}$ sink expressed as lower $\mathrm{N}$ uptake per unit of yield).

5. Improving the synchronization of planting and harvesting operations with shifts in the hydrologic cycle (rainy season).

6. Managing soil and crops to increase water-use efficiencies.

7. Valuing agricultural commodities for their water footprint or environmental traits.

8. Increasing soil C sequestration to improve soil functions.

9. Increasing $\mathrm{N}$-use efficiencies for cropping systems.

10. Applying the concepts of precision/ target conservation to increase conser- vation effectiveness across spatial and temporal variability.

\section{CONCLUSION}

It has been reported that GHGs emitted into the atmosphere by human activities have increased radiative forcing and caused an increase in the global mean temperature of approximately $0.74^{\circ} \mathrm{C} \quad\left(1.33^{\circ} \mathrm{F}\right)$ over the past century. In terms of soil conservation, expected consequences of future climate change include changes to soil erosion rates and associated water quality problems, as well as the need to adjust the conservation planning process to meet continually changing rainfall intensities. It is important to apply conservation practices to conserve water quantity and quality (e.g., practices that have higher water-use efficiencies and/or that reduce off-site transport of soil and agrochemicals to water bodies). The threat of climate change, together with other concerns, could contribute to a global problem that will impact food security and resource availability if we do not act to prepare ourselves. Some of these concerns that can interact with climate change and extreme weather events are desertification, deforestation, depletion of groundwater resources, higher energy costs, plant diseases, and population growth and higher demand for food production. It is clear as we look ahead to the next four decades that we need to maximize agricultural production, due to the continuously growing food demand that comes with world population growth, while maximizing soil and water conservation.

This document reviews the science of conservation and climate change. Although there is no silver bullet that will address every site-specific situation, the literature suggests there are practices that are beneficial in certain situations. There is the need for additional research, transfer/dissemination of information, and application of soil and water conservation programs that integrate maximum agricultural productivity with practices that can mitigate climate change and/or help us adapt to it.

The advantages of bioenergy programs that minimize environmental impacts were also reviewed. Whatever decisions societies make, there are some basic principles 
that need to be considered in conservation agriculture: (1) minimum soil tillage disturbance, (2) diverse crop rotations and/ or cover crops, and (3) continuous plant residue cover, loosely described as notill/direct seeding systems. Wherever it is economical and viable to do so, farmers should integrate all aspects of conservation agriculture as part of agriculture's transition to sustainability. Site-specific precision conservation practices can be used to increase conservation effectiveness. There is a definite need for more scientific research to enhance food production while minimizing human impact on environmental quality. The expanding global population necessitates further research on developing sustainable food production systems on the very limited and fragile soil systems that support our existence. More conservation with emphasis on minimum soil disturbance and maximum C management will be required for sustainable production so important to future generations.

Adaptive and mitigating solutions will be complex and evolving. Climate change and climate variability present us with moving targets. Ecosystems are interconnected and interdependent natural resources. It is important to look at the whole to recognize stresses on individual components. We must develop collaborative, interdisciplinary approaches to be more efficient and to recognize the interconnectedness of the resources. Decades of stress ahead will also bring opportunities and innovation to those acting proactively.

\section{ACKNOWLEDGEMENTS}

Special thanks and acknowledgements to Oksana Gieseman, Director of Publications, and Jacqueline Pohl, Editorial Assistant, Soil and Water Conservation Society, and Donna Neer, Biological Science Technician, USDA Agricultural Research Service, for their contributions in helping to edit this document. Special thanks and acknowledgement are also extended to the following peers: (1) Lorenzo Borselli, Researcher, Consiglio Nazionale delle Ricerche Istituto di Ricerca per la Protezione Idrogeologica, Firenze, Italy; (2) John Westra, Associate Professor, Department of Agricultural Economics and Agribusiness, Louisiana State University, Baton Rouge, Louisiana; (3) Theo Dillaha, Professor,
Department Biological Systems Engineering, Virginia Polytechnic Institute and State University, Blacksburg, Virginia; (4) Neville Millar, Visiting Senior Research Associate, Michigan State University, W.K. Kellogg Biological Station, Hickory Corners, Michigan; (5) R. Scott Van Pelt, Soil Scientist, USDA Agricultural Research Service, Wind Erosion and Water Conservation Research Unit, Big Spring, Texas; (6) M.S. Srinivasan, Hydrologist, National Institute of Water \& Atmospheric Research Ltd., New Zealand; (7) Raul Lavado, Professor, University of Buenos Aires, College of Agronomy Buenos Aires, Argentina; and (8) Wanhong Yang, Associate Professor, Department of Geography, University of Guelph, Guelph, Ontario, Canada, for their contributions in reviewing this document. The Soil and Water Conservation Society invited the authors to review the science of conservation practices and their potential for climate change mitigation and adaptation. This scientific overview was accepted on April 26th, 2011

We also want to acknowledge that there are hundreds of manuscripts that have been published about the benefits of conservation practices in the United States and other countries. Our goal was to prepare a short overview of the scientific literature, reviewing what is known about the effects of applied conservation practices on GHG emissions and the impacts of climate change on conservation, and identifying current needs of research and technology efforts in this area. We wanted to identify major world challenges that interconnect food security with climate change and soil and water conservation. We have identified principles for (1) communication of soil and water conservation programs, (2) soil and water conservation practices, and (3) development of new science and technologies. These three sets of principles can all be applied to climate change mitigation and adaptation. We hope that this feature article has helped start a conversation with members of the Soil and Water Conservation Society, other professional societies, and the general public about the importance of the science of conservation and how it can contribute to climate change mitigation and adaptation.

Mention of trade names or commercial products in this publication is solely for the purpose of providing specific information and does not imply recommendation or endorsement by the USDA.

\section{DISCLAIMER}

The review covers a wide range of management practices that can potentially be employed in certain conditions and regions to mitigate and/or adapt to climate change. It is recognized that there are a great number of other mitigating and adaptive practices mentioned in the scientific literature that are not discussed in the review. Due to limitations of space and time, not all practices or combinations of practices are included. Thus, readers must keep in mind throughout this review that there are other practices that, in certain regions and conditions, may also have the potential to mitigate climate change or be used as an adaptive response to climate change.

\section{REFERENCES}

Adler, P.R., S.J. Del Grosso, and W.J. Parton. 2007. Life-cycle assessment of net greenhouse-gas flux for bioenergy cropping systems. Ecological Applications 17:675-691.

Auffhammer, M. 2011. Weather dilemma for African maize. Nature Climate Change 1:27-28 http:// www.nature.com/natureclimatechange.

Batan L., J. Quinn, B. Willson, and T. Bradley. 2010. Net energy and greenhouse gas emission evaluation of biodiesel derived from microalgae. Environmental Science Technology 44:7975-7980.

Berry, J.K., J.A. Delgado, R. Khosla, and FJ. Pierce. 2003. Precision conservation for environmen $\neg$ tal sustainability. Journal of Soil and Water Conservation 58(6):332-339.

Bryan, E., T.T. Deressa, G.A. Gbetibouo, and C. Ringler. 2009. Adaptation to climate change in Ethiopia and South Africa: Options and constraints. Environmental Science and Policy 12:413-426.

Bucks, D.A., T.W. Sammis, and G.L. Dickey. 1990. Irrigation for arid areas. In Management of farm irrigation systems, ed. G.J. Hoffman, T.A. Howell, and K.H. Solomon, 499-548. Saint Joseph: American Society of Agricultural Engineers.

Cayan, D.R., T. Dasa, D.W. Piercea, T.P. Barnetta, M Tyreea, and A. Gershunova. 2010. Future dryness in the southwest US and the hydrology of the early 21st century drought. Proceedings of the National Academy of Sciences 107:21271-21276

CCSP (US Climate Change Science Program). 2008.

The effects of climate change on agriculture, land resources, water resources, and biodiversity in the United States. A Report by the United States Climate Change Science Program and the Subcommittee on Global Change Research. eds. P. Backlund, A. Janetos, D. Schimel, J. Hatfield, K. Boote, P. Fay, L. Hahn, C. Izaurralde, B.A. Kimball, T. Mader, J. Morgan, D. Ort, W. Polley, A. Thomson, D. Wolfe, M.G. Ryan, S.R. Archer, R. Birdsey, C. Dahm, L. Heath, J. Hicke, D. Hollinger, T. Huxman, G. Okin, R. Oren, J. Randerson, W. 
Schlesinger, D. Lettenmaier, D. Major, L. Poff, S. Running, L. Hansen, D. Inouye, B.P. Kelly, L. Meyerson, B. Peterson, and R. Shaw. Washington, DC: USDA.

Cruse, R.M., and C.G. Herndl. 2009. Balancing corn stover harvest for biofuels with soil and water conservation. Journal of Soil and Water Conservation 64(4):286-291, doi:10.2489/ jswc.64.4.286.

Delgado, J.A., M.A. Dillon, R.T. Sparks, and S.Y.C. Essah. 2007. A decade of advances in cover crops: Cover crops with limited irrigation can increase yields, crop quality, and nutrient and water use efficiencies while protecting the environment. Journal of Soil and Water Conservation 62:110A-117A.

Delgado, J.A. 2010. Crop residue is a key for sustaining maximum food production and for conservation of our biosphere. Journal of Soil and Water Conservation 65(5):111A-116A, doi:10.2489/jswc.65.5.111A.

Delgado, J.A., S.J. Del Grosso, and S.M. Ogle. 2010. ${ }^{15} \mathrm{~N}$ Isotopic crop residue cycling studies suggest that IPCC methodologies to assess $\mathrm{N}_{2} \mathrm{O}-\mathrm{N}$ emissions should be reevaluated. Nutrient Cycling in Agroecosystems 86:383-390.

Eagle, A.J., L.R. Henry, L.P. Olander, K. HaugenKozyra, N. Millar, and G.P. Robertson 2010. Greenhouse Gas Mitigation Potential of Agricultural Land Management in the United States: A Synthesis of the Literature. Technical Working Group on Agricultural Greenhouse Gases (T-AGG) Report. Durham, NC: Nicholas Institute for Environmental Policy Solutions, Duke University. http://nicholasinstitute.duke. edu/ecosystem/land/TAGGDLitRev.

FAO (Food and Agriculture Organization of the United Nations). 2009. Agriculture and Consumer Protection Department. Conservation Agriculture. Food and Agriculture Organization of the United Nations. http://www.fao.org/ $\mathrm{ag} / \mathrm{ca} /$.

Gleick, P.H., R.M. Adams, R.M. Amasino, E. Anders, D.J.Anderson, W.W. Anderson, L.E. Anselin et al. 2010. Climate change and the integrity of science. Science 328:689-690.

Hatfield, J.L., and J.H. Prueger. 2004. Impacts of changing precipitation patterns on water quality. Journal of Soil and Water Conservation 59(1):51-58.

Iglesias, A., K. Avis, M. Benzie, P. Fisher, M. Harley, N. Hodgson, L. Horrocks, M. Moneo, and J. Webb. 2007. Adaptation to climate change in the agricultural sector. Report to European Commission Directorate - General for Agriculture and Rural
Development. AEA Energy \& Environment and Universidad de Politécnica de Madrid.

IPCC (Intergovernmental Panel on Climate Change). 2007. Summary for Policymakers. In Climate Change 2007: The Physical Science Basis. Contribution of Working Group I to the Fourth Assessment Report of the Intergovernmental Panel on Climate Change, eds. S. Solomon, D. Qin, M. Manning, Z. Chen, M. Marquis, K.B. Averyt, M. Tignor and H.L. Miller. Cambridge, United Kingdom, and New York, USA: Cambridge University Press. https:// www.ipcc-wg1.unibe.ch/publications/wg1-ar4/ ar4-wg1-spm.pdf.

Jawson, M.D., S.R. Shafer, A.J. Franzluebbers, T.B. Parkin, and R.F. Follett. 2005. GRACEnet: Greenhouse gas Reduction through Agricultural Carbon Enhancement network. Soil \& Tillage Research 83:167-172.

Johnson, J.M.F., M.D. Coleman, R. Gesch, A. Jaradat, R. Mitchell, D. Reicosky, and W.W. Wilhelm. 2007. Biomass-Bioenergy Crops in the United States: A Changing Paradigm. The Americas Journal of Plant Science and Biotechnology $1: 1-28$.

Johnson, J.M.F., D.L. Karlen, and S.S. Andrews. 2010. Conservation considerations for sustainable bioenergy feedstock production: If, what, where, and how much? Journal of Soil and Water Conservation 65(4):88A-91A, doi:10.2489/ jswc.65.4.88A.

Karl, T.R., and R.W. Knight. 1998. Secular trends of precipitation amount, frequency, and intensity in the USA. Bulletin of the American Meteorological Society 79:231-241.

Lal, R. 2002. Carbon sequestration in dryland ecosystems of West Asia and North Africa. Land Degradation and Development 13:45-59.

Lemmen, D.S., and F.J. Warren, ed. 2004 Climate change impacts and adaptation: A Canadian perspective. Natural Resources Canada, Ottawa.

Lobell, D.B., M. Bänziger, C. Magorokosho, and B. Vivek. 2011. Nonlinear heat effects on African maize as evidenced by historical yield trials. Nature Climate Change 1:42-45. http://www. nature.com/natureclimatechange.

Lybbert, T., and D. Sumner. 2010. Agricultural technologies for climate change mitigation and adaptation in developing countries: Policy options for innovation and technology diffusion. ICTSD-IPC Platform on Climate Change, Agriculture and Trade, Issue Brief No.6, Geneva, Switzerland: International Centre for Trade and Sustainable Development, and Washington DC, USA: International Food \& Agricultural
Trade Policy Council. http://ictsd.org/ downloads/2010/06/agricultural-technologiesfor-climate-change-mitigation-and-adaptationin-developing-countries_web.pdf.

Madsen, T., and E. Figdor. 2007. When it rains, it pours: Global warming and the rising frequency of extreme precipitation in the United States. Providence, RI: Environment America Research and Policy Center.

Mausbach M.J., and A.R. Dedrick. 2004. The length we go: Measuring environmental benefits of conservation practices. Journal of Soil and Water Conservation 59(5):96A-103A.

Montgomery, D.R. 2007. Soil erosion and agricultural sustainability. Proceedings of the National Academy of Sciences 104:13268-13272.

Mutuo, P.K., G. Cadisch, A. Albrecht, C.A. Palm, and L.Verchot. 2005. Potential of agroforestry for carbon sequestration and mitigation of greenhouse gas emissions from soils in the tropics. Nutrient Cycling in Agroecosystems 71:43-54.

Nearing, M.A., F.F. Pruski, and M.R. O’Neal. 2004. Expected climate change impacts on soil erosion rates: A review. Journal of Soil and Water Conservation 59(1):43-50.

Peng, S., J. Huang, J.E. Sheehy, R.C. Laza, R.M. Visperas, X. Zhong, G.S. Centeno, G.S. Khush, and K.G. Cassman. 2004. Rice yields decline with higher night temperature from global warming. Proceedings of the National Academy of Sciences 101:9971-9975.

Pennock, D.J. 2005. Precision conservation for comanagement of carbon and nitrogen on the Canadian prairies. Journal of Soil and Water Conservation 60(6):396-401.

Quine, T.A., and Y. Zhang. 2002. An investigation of spatial variation in soil erosion, soil properties, and crop production within an agricultural field in Devon, United Kingdom. Journal of Soil and Water Conservation 57(1):55-64.

Ramanathan, V., and Y. Xu. 2010. The Copenhagen Accord for limiting global warming: Criteria, constraints and available avenues. Proceedings of the National Academy of Sciences of the United States of America 107(18):8055-8062

Rangely, W.R. 1987. Irrigation and drainage in the world. In Proceedings of water and water policy in world food supplies, conference held in College Station, Texas, ed. W.R. Jordan, 29-35. College Station, TX: Agriculture and Mining University Press.

Roberts, T.L. 2007. Right product, right rate, right time and right place... the foundation of best management practices for fertilizer. In Fertilizer Best Management Practices: General 
Principles, Strategies for their Adoption and Voluntary Initiatives vs Regulations. Paper presented at the IFA International Workshop on Fertilizer Best Management Practices, Brussels, Belgium, March 7-9 2007, 29-32. Paris, France: International Fertilizer Industry Association. http://www.fertilizer.org/ifa/ HomePage/LIBRARY/Conference-papers/ Agriculture-Conferences/2007-IFA-FBMP.

Schenk, P.M., S.R. Thomas-Hall, E. Stephens, U.C. Marx, J.H. Mussgnug, C. Posten, O. Kruse and B. Hankamer. 2008. Second generation biofuels: High-efficiency microalgae for biodiesel production. Bioenergy Research 1:20-43

Silici, L. 2010. Conservation Agriculture and Sustainable Crop Intensification in Lesotho. Rome, Italy: Food and Agriculture Organization of the United Nations (FAO). http://www.fao. org/docrep/012/i1650e/i1650e00.pdf.

Stern, N. 2006. Stern Review on the Economics of Climate Change. HM Treasury, UK Government. http://webarchive.nationalarchives.gov. uk/+/http://www.hm-treasury.gov.uk/ independent_reviews/stern_review_economics_climate_change/sternreview_index.cfm.

Thiombiano, L., and M. Meshack. 2009. Scaling-up Conservation Agriculture in Africa: Strategy and Approaches. Addis Ababa, Ethiopia: Food and Agriculture Organization of the United Nations (FAO) Sub Regional Office for Eastern Africa.
http://www.fao.org/ag/ca/doc/Kenya\%20 Workshop\%20Proceedings.pdf.

Tribe, D. 1994. Feeding and Greening the World, the Role of Agricultural Research. Wallingford, UK: Commonwealth Agriculture Bureau.

UNEP GRID-Arendal (United Nations Environment Programme GRID-Arendal). 2009. From supply to food security. In The Environmental Food Crisis: The Environment's Role in Averting Future Food Crisis. A UNEP Rapid Response Assessment, eds. C. Nellemann, MacDevette, M., Manders, T., Eickhout, B.,Svihus, B., Prins, A.G., and Kaltenborn, B.P., 77-91. Norway: Birkeland Trykkeri AS. http://www.grida.no/publications/ rr/food-crisis/page/3571.aspx.

UNFCC (United Nations Framework Convention on Climate Change). 2007. Climate Change: Impacts, vulnerabilities and adaptation in developing countries. Bonn, Germany: United Nations Framework Convention on Climate Change. http://unfccc.int/resource/docs/publications/impacts.pdf.

USDA NRCS (Natural Resources Conservation Service). 2010. Agriculture Secretary Vilsack Announces New Steps to Meet the Challenge of Climate Change. USDA Natural Resources Conservation Service. USDA Office of Communications. Release No. 0642.10 http:// www.nrcs.usda.gov/news/releases/2010/cig_ ghg_12.09.10.html.
USDA NRCS. n.d. Quotes from Hugh Hammond Bennett. USDA Natural Resources Conservation Service. http://www.nrcs.usda.gov/about/history/quotes.html.

USEPA (US Environmental Protection Agency). 2010a. Climate Change Indicators in the United States. http://www.epa.gov/climatechange/indicators/pdfs/ClimateIndicators_full.pdf.

USEPA. 2010b. Inventory of U.S. Greenhouse Gas Emissions and Sinks: 1990-2008. Washington, DC: USEPA. http://www.epa.gov/climatechange/ emissions/downloads10/508_Complete_ GHG_1990_2008.pdf.

Verdin, J., C. Funk, G. Senay, and R. Choularton. 2005. Climate science and famine early warning. Philosophical Transations of the Royal Society 360:2155-2168.

Walter, T., M. Dosskey, M. Khanna, J. Miller, M. Tomer, and J. Weins. 2007. The science of targeting within landscapes and watersheds to improve conservation effectiveness. In Managing Agricultural Landscapes for Environmental Quality: Strengthening the Science Base, ed. M. Schnepf and C. Cox, 63-89. Ankeny, IA: Soil and Water Conservation Society.

WEF (World Economic Forum). 2011 Global Risks 2011 Sixth Edition. Geneva, Switerland: World Economic Forum. http://riskreport. weforum.org. 